\title{
Public Perception on Attributes of Walking Avenue in Urban Areas of Sri Lanka
}

\author{
Dissertation Submitted to the \\ University of Sri Jayewardenepura \\ as a Partial Fulfillment for the \\ Requirements of the Final Examination of the \\ M.sc in Real Estate Management and Valuation Degree
}

$\begin{array}{ll}\text { Name } & \text { : J.L.I. Dilhan } \\ \text { Reg. No } & : \text { GSIM.Sc/REMV//3755/09 } \\ \text { Department } & : \text { Department of Estate Management and valuation } \\ \text { University } & : \text { University of Siri Jaye } \\ \text { Date of Surdenepura } & \end{array}$ 


\section{Student Declaration}

The work described in this dissertation was carried out under the supervision of Ms. Nisani Wickramaarachchi and any report on this have not been submitted in whole or in part to any university or any other institute for another degree/examination or any other purpose.

Name : Jalenthi Lekamlage Indrajith Dilhan

Reg. No : GS/M.Sc/REMV/3755/09

Exam No: REMV 67

Signature: ................ Dell

Date $\quad: 27^{\text {th }}$ June 2014 
Hereby, I certify that Mr. J.L.I.Dilhan (Reg No: GS/M.Sc/REMV/3755/09) duly completed the recommended corrections of the research on Public Perception on Attributes of Walking Avenues in Urban Areas of Sri Lanka under my supervision and recommended for final submission.

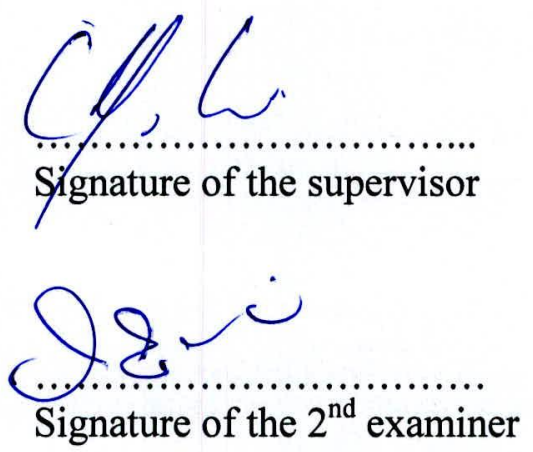

Signature of the Head of Department 


\section{Acknowledgement}

First of all, I would like to thank Ms. N.C. Wickramarchchi, Senior Lecturer, Department of Estate Management and Valuation, University of Sri Jayewardenepura for being my supervisor and having faith in me for carrying the responsibility of doing research under her profound guidance. Her prominence in giving me this opportunity and her constant attention and support through out my research conferred me with a sense of responsibility. She was always there to help to me at all times. Apart from a wonderful teacher she is great human being and I respect her from the depth of my Heart.

I wish to my sincere thanks to Professor R.G Ariyawansa, Coordinator, Head of the Department of Estate Management and Valuation, University of Sri Jayewardenepura for giving valuable instruction regarding my research.

I wish to my sincere thanks to Ms. Janaki Edirisingha, Senior Lecturer, former Head of the Department of Estate Management and Valuation, University of Sri Jayewardenepura for giving valuable instruction regarding my research.

And also I would like to thank Urban Development Authority and Provincial Road Development Authority and Sri Lanka Land Reclamation Development Corporation for giving information regarding my research.

And my sincere thanks go to my batch mates and friends for providing support to of this task 


\begin{abstract}
To find large areas close to urban areas to build recreational facilities is impossible when compare with the current demand for urban land resource. After identifying of narrow strips of stream bank reservations as a prime space available for this purpose created and designed the new concept of walking paths. The purpose of this study is to examine the public perceptual preferences on relevant attributes of walking avenues in selected case studies. The study also aims to analyze public preference willingness to maintain attributes. A total of 10 environmental attributes were identified from earlier Qualitative and Quantitative studies. Participants were asked questions basically focused on their preference and their social characteristics. Robust test of equality of Means and Homogenous Subsets techniques were used to analyze preference of respondents and descriptive analysis method was used to analyze willingness to maintain of attributes. The results were grouped in to five and then ranked. The most prioritized character is Safety (Safety of male, Safety of Female) while Facility of Toilet, Availability of Shading, Availability of landscape, Availability of Natural View were the next preferred attributes. The findings can assists those involved in designing and managing outdoor environment to identify salient environmental attributes and prioritize them in providing. The approach aids to understanding what are the attributes to be provided at what cost to the walking path users. This is a more research - exposed category of urban recreational settings due to walking paths is a newly introduced urban planning element to Sri Lanka. Therefore, association between walking paths and land value, formulating standards to walking paths, Controverts of river bank reservations with walking path construction etc areas to be further researched.
\end{abstract}




\section{Table of Contents}

\author{
Acknowledgement \\ Abstract \\ Table of content \\ List of table \\ List of figure \\ List of map
}

Page No
$i$
$i i$
$i i i$
$v i i$
$x$
$x i$

Page No

Contents

\section{CHAPTER ONE - Introduction}

$\begin{array}{ll}1.1 \text { Background of the study } & 01\end{array}$

$\begin{array}{ll}1.2 \text { Statement of problem } & 04\end{array}$

$\begin{array}{ll}1.3 \text { Significance of the study } & 05\end{array}$

$\begin{array}{ll}1.4 \text { Objectives of the study } & 05\end{array}$

1.4.1 General Objective $\quad 05$

$\begin{array}{ll}\text { 1.4.2 Specific Objectives } & 05\end{array}$

1.5 Methodology 06

1.6 Limitations of the study 06

\section{CHAPTER TWO - Literature Review}

$\begin{array}{ll}2.1 \text { Introduction } & 07\end{array}$

2.2 Concepts related to Public Open Spaces $\quad 07$

$\begin{array}{ll}2.2 .1 \text { Recreation } & 07\end{array}$

2.3 History of Outdoor Recreation $\quad 09$

2.3.1 Garden City and City Beautiful Movement Theory 09

2.3.2 The Neighborhood Unit Concept in theory and application 11

2.4 Public Open Spaces 13

2.5 Empirical Evidences $\quad 15$

2.5.1 Factors affecting use of urban parks $\quad 15$

$\begin{array}{ll}2.5 .2 \text { Necessity of walking paths } & 17\end{array}$

2.5.3 Benefits of Urban Parks $\quad 19$

2.5.4 Barriers on park visitation $\quad 22$

2.5.5 Socio-demographic Factors concerned in other researches 24

2.5.6 Attributes concerned in other researches 26

2.5.6.1 Cafeteria and Sanitary 26

2.5.6.2 Availability of Benches 27

2.5.6.3 Quality of Environment 27

2.5.6.4 Landscape $\quad 27$

2.5.6.5 Quality of footpaths 28

2.5.6.6 Scenic Beauty 28

2.5.6.7 Safety 29 


\section{CHAPTER THREE - Research Design}

3.1 Research Design

3.2 Methodology

3.3 Problem Identification

3.4 Formulating objectives $\quad 34$

3.4.1 Research Objectives $\quad 34$

3.4.1.1 General Objective $\quad 34$

3.4.1.2. Specific Objective $\quad 34$

3.5 Selection of case study area $\quad 34$

3.6 Sample Design $\quad 35$

3.7 Data Collection $\quad 35$

3.7.1 Primary Data Collection Method 35

3.7.2 Secondary Data Collection Method 36

3.8 Data Analysis 36

3.8.1 First Objective $\quad 36$

3.8.2 Second Objective $\quad 36$

3.8.3 Third objective $\quad 38$

3.9 Data Arrange 38

3.10 Result Representation $\quad 39$

\section{CHAPTER FOUR - Case Study}

4.1 Introduction 40

4.2 Diyawanna Oya Bank walking path at Parliment 41

4.2.1 Demographics - Population $\quad 42$

4.2.2 Area $\quad 42$

4.2.3 Topography $\quad 42$

4.2.4 Soil type \& Quality $\quad 42$

4.2.5 Surface water $\quad 44$

4.2.6 Ground Water $\quad 44$

4.2.7 Images of the Location $\quad 44$

4.3 Oruthota Walking path in Gampaha $\quad 45$

4.4. Mahara Dalupitiya Walking path 50

\section{CHAPTER FIVE - Data Analysis}

5.1 Introduction $\quad 54$

5.2 Descriptive Analysis $\quad 54$

5.2.1 Locational Analysis $\quad 54$

5.2.2 Analysis of the characteristics of selected case study areas $\quad 55$ 
5.2.3 Analysis of the socio economic characteristics of users

5.2.3.1 Gender

5.2.3.2 Age categorization of respondents

5.2.3.3 Educational Level

5.2.3.4 Types of Employment $\quad 58$

5.2.3.5 Time of visit of users $\quad 59$

5.2.3.6 Number of visit per week $\quad 59$

5.2.3.7 Purpose of using walking Area $\quad 60$

5.2.3.8 Preferred time of visiting $\quad 60$

5.2.3.9 Hours Spending in Walking Paths 62

5.2.3.10 Mode of Travel and Distance from Home 63

5.2.3.11 Income Level of respondents 64

5.3 To analyze the necessity of attributes in relation to each Social characteristics of users

5.3.1 Analysis of the association of social factors (Gender, Age, Education, Employment type and Income level) with facility of Toilet

5.3.2 Analysis of the association of social factors (Gender, Age, Education, Employment type and Income level) with Facilities of Changing rooms

5.3.3 Analysis of the association of social factors (Gender, Age, Education, Employment type and Income level) with Facilities of Cafeteria.

5.3.4 Analysis of the association of social factors (Gender, Age, Education, Employment type and Income level) with Street vendor

5.3.5 Analysis of the association of social factors (Gender, Age, Education, Employment type and Income level) with Car Parking Facilities

5.3.6 Analysis of the association of social factors (Gender, Age, Education, Employment type and Income level) with availability of bench

5.3.7 Analysis of the association of social factors (Gender, Age, Education, Employment type and Income level) with availability of Shading

5.3.8 Analysis of the association of social factors (Gender, Age, Education, Employment type and Income level) with availability of Land Scape

5.3.9 Analysis of the association of social factors (Gender, Age, Education, Employment type and Income level) with available Natural view

5.3.10 Analysis of the association of social factors (Gender, Age, Education, Employment type and Income level) with availability Safety 
5.5 Test of Homogeneity of Variances used for determines

whether all above variances are same or not.

5.5.1 Robust test of equality of Means were apply to check whether means of all dimensions are same or not

5.5.2 Using Post Hoc Multiple Comparisons for Observed mean, Check means of dimensions.

5.6 Identification of Homogenous Subsets

5.7 Ranking

5.8 To analyze the public preferences on the willingness to maintain the attributes

5.8.1 Preferred to pay for facility of Toilets 93

5.8.2 Preferred to pay for facility of Changing Room 94

5.8.3 Preferred to pay for facility of Car park 95

5.8.4 Preferred Type of Cafeteria Facility 96

5.8.5 Expected Service Facilities 99

5.8.6 Nature of Street Venders 100

5.8.7 Distance between Two Clusters of Bench 103

\section{CHAPTER SIX - Conclusion and Recommendation}

$\begin{array}{ll}6.1 \text { Conclusion } & 105\end{array}$

6.2 Recommendation 113

References $\quad 115$

$\begin{array}{ll}\text { Annexure } & 124\end{array}$ 


\section{LIST OF TABLES}

\section{Table No}

Page No

2.1 Characteristics of Recreational Open Spaces

4.1 Location of selected case study area 40

4.2 Water quality fluctuations in the Diyawanna Oya 44

5.1 Situation of selected locations $\quad 54$

5.2 Characteristics of selected Walking Avenues 55

5.3 Gender composition of respondents in Parliment Walking path 56

5.4 Gender composition of respondents in Oruthota Walking path 56

5.5 Gender composition of respondents in Kiribathgoda Walking Path

5.6 Age categorization of respondents 57

5.7 Education levels of respondents $\quad 57$

5.8 Types of Employment 58

5.9 Time of visit of users $\quad 59$

5.10 Number of visit per week $\quad 59$

5.11 Purpose of using walking Area $\quad 60$

5.12 Preferred time of visiting in Parliment Walking path $\quad 60$

5.13 Preferred time of visiting in Oruthota Walking path $\quad 61$

5.14 Preferred time of visiting in Kiribathgoda Walking path $\quad 61$

5.15 Hours Spending in Parliment Walking path 62

5.16 Hours Spending in Oruthota Walking path 62

5.17 Hours Spending in Kiribathgoda Walking path 63

5.18 Income Level of Parliment Walking path users $\quad 65$

5.19 Income Level of Oruthota Walking path users 66

5.20 Income Level of Kiribathgoda Walking path users $\quad 66$

5.21 Analysis of the association of social factors (Gender, Age, Education, Employment type and Income level) with Facilities of Toilet

5.22 Analysis of the association of social factors (Gender, Age, Education, Employment type and Income level) with Facilities of Changing rooms

5.23 Analysis of the association of social factors (Gender, Age, Education, Employment type and Income level) with Facilities of Cafeteria.

5.24 Analysis of the association of various income categories with Facilities of Cafeteria

5.25 Analysis of the association of social factors (Gender, Age, Education, Employment type and Income level) with Street vendor

5.26 Analysis of the association of social factors (Gender, Age, Education, Employment type and Income level) with Car Parking Facilities 
5.27 Analysis of the association of social factors (Gender, Age, Education, Employment type and Income level) with availability of bench

5.28 Analysis of the association of social factors (Gender, Age, Education, Employment type and Income level) with availability of Shading

5.29 Analysis of the association of social factors (Gender, Age, Education, Employment type and Income level) with availability of Land Scape

5.30 Analysis of the association of social factors (Gender, Age, Education, Employment type and Income level) with available Natural view

5.31 Analysis of the association of social factors (Gender, Age, Education, Employment type and Income level) with availability Safety

5.32 Test of Homogeneity of Variances 86

5.33 Robust test of equality of Means 87

5.34 Post Hoc Multiple Comparisons for Observed mean $\quad 88$

5.35 Identification of Homogenous Subsets 91

5.36 Median and Mode of Prefer to pay for facility of Toilets 93

5.37 Preferred to pay for facility of Toilets 93

5.38 Median and Mode of Prefer to pay for facility of Changing Room 94

5.39 Preferred to pay for facility of Changing Room 94

5.40 Median and Mode of Prefer to pay for facility of Car park 95

5.41 Preferred to pay for facility of Car park for Two Wheel 95

5.42 Preferred to pay for facility of Car park for Three Wheel 96

5.43 Preferred to pay for facility of Car park for Four Wheel 96

5.44 Median and Mode of Prefer Type of Cafeteria Facility 97

5.45 Preferences on Heavy Foods 97

5.46 Preferences on Short eats 97

5.47 Preferences on Healthy and herbal drinks 98

5.48 Preferences on soft drinks, water, juices 98

5.49 Preferences on Seating place 98

5.50 Preferences on Litter bins 99

5.51 Median and Mode of Expected Service Facilities 99

5.52 Expected Service Facilities 100

5.53 Median and Mode of Nature of Street Venders $\quad 100$

5.54 preferred on ice cream Street Venders 101

5.55 preferred on Bun, Short eats - foods Street Venders 101

5.56 preferred on Water Bottles Street Venders 102

5.57 preferred on Herbal Drinks Street Venders 102

5.58 preferred on King Coconut Street Venders 103 
5.59 Median and Mode of Distance between Two Clusters of Bench

103

5.60 Distance between Two Clusters of Bench

104 


\section{LIST OF FIGURES}

Figure No

Page No

2.1 Garden City

09

2.2 Garden City

10

2.3 The relationship between parks and physical activity.

20

5.1 Mode of Travel to Walking paths

63

5.2 Distance from Home to Walking paths

64 


\section{LIST OF MAPS}

Map No

4.1 Location map of Diyawanna Oya walking path

4.2 Soil Maps of the Study Area

4.3 Location map of Oruthota Walking path in Gampaha

4.3.1 Description

4.3.2 Population

4.3. Location map of Mahara Dalupitiya Walking path
Page No

41

43

47

47

48

51 


\section{CHAPTER ONE}

\section{Introduction}

\subsection{Background of the study}

Public open spaces such as city squares, parks, beaches and sidewalks tend to keep the city and integrate the function of the city with other urban components. These places become locations for people to meet, relax and exchange ideas as well as centers for various activities that improve the physical and social environment of the city. Public open spaces includes things such as Parks, playgrounds, Beaches, Natural Views, observation places etc. Most of the countries give priority for the urban parks and open space in the city design. Public open spaces play multiple roles in making our cities more sustainable. These are regarded as an essential element for people's recreation and healthy living and also include nature's services, ecological benefits e.g: preserving bio diversity, social benefits e.g: socialization and healthy living, and economic benefits e.g: tourism etc.

Designation of public open space is an integral component of urban development planning. It shows that open space benefits provide considerable potential cost savings to local authorities. e.g: preventing health problems, increasing worker's productivity, lessening infrastructure damage, attenuating flooding, etc. Strong evidence shows that when people have access to open spaces, they exercise more. Researches show that contact with the natural world improves physical and psychological health. According to the view of Sherer, 2003, open space visionaries, parks were not amenities; they were necessities, providing recreation, inspiration and essential respite from the city's blare and bustle. And the visionaries were particularly concerned that open spaces be available to all of a city's residents.

Urban parks and open spaces are major part in the urban design in the world. Most of the countries give major priority for the urban parks and open space in the city design. Sherer, 2003, found that, many of the nation's great city parks were built in the second half of the $19^{\text {th }}$ century. Urban planners believed the parks and open spaces would improve public health, relieve the stresses of urban life, and create a democratizing public space where rich and poor would mix on equal terms. By mid$20^{\text {th }}$ century, city parks fell into decline as inner cities fled for the suburbs. 